\title{
The Role of the "Inter-Life" Virtual World as a Creative Technology to Support Student Transition into Higher Education
}

\author{
Alison M. Devlin, Vic Lally, Brian Canavan, Jane Magill \\ Interdisciplinary Science Education, Technologies and Learning Research Group, \\ School of Education, College of Social Sciences, University of Glasgow, Glasgow, UK \\ Email: Alison.Devlin@Glasgow.ac.uk
}

Received June $13^{\text {th }}, 2013$; revised July $12^{\text {th }}, 2013$; accepted July $19^{\text {th }}, 2013$

Copyright (C) 2013 Alison M. Devlin et al. This is an open access article distributed under the Creative Commons Attribution License, which permits unrestricted use, distribution, and reproduction in any medium, provided the original work is properly cited.

\begin{abstract}
The shape of Higher Education (HE) in the UK and internationally is changing, with wider access policies leading to greater diversity and heterogeneity in contemporary student populations world-wide. Students in the 21 st Century are often described as "fragmented"; meaning they are frequently working whilst participating in a full time Degree programme. Consequently, those in the HE setting are required to become "future ready" which increasingly involves the seamless integration of new digital technologies into undergraduate programmes of teaching and learning. The present study evaluated the effectiveness of the "Inter-Life" three-dimensional virtual world as a suitable Technology Enhanced Learning (TEL) tool to support the initial stages of transition from school into university. Our results demonstrate that Inter-Life is "fit for purpose" in terms of the robustness of both the educational and technical design features. We have shown that Inter-Life provides a safe space that supports induction mediated by active learning tasks using learner-generated, multi-modal transition tools. In addition, through the provision of private spaces, Inter-Life also supports and fosters the development of critical reflective thinking skills. However, in keeping with the current literature in the field, some of the students expressed a wish for more training in the functional and social skills required to navigate and experience the Inter-Life virtual world more effectively. Such findings resonate with the current debate in the field which challenges the notion of "digital natives", but the present study has also provided some new evidence to support the role of virtual worlds for the development of a suitable community to support students undergoing transition to university.
\end{abstract}

Keywords: Inter-Life; Transition; Higher Education; Virtual Worlds; Community; Technology Enhanced Learning

\section{Introduction}

The shape of Higher Education (HE) in the UK and internationally is changing due to the global "knowledge economy" (Robertson, 2005; Facer \& Sandford, 2010; Biesta, 2011). Furthermore, universities have been affected by wider access policies and now have an increasingly diverse student population (Christie, 2009). Students in the 21st Century are balancing competing demands and are frequently working whilst participating full time in HE, and have come to be described as "consumers" of Education (Leese, 2010). With such an increase in global competition, universities are now required to be "future ready" in times of economic challenge and uncertainty (Selwyn, 2007, 2010). Being future ready increasingly involves the need to incorporate innovative digital technologies that most students experience as part of their everyday life. The transition into university has been extensively studied in the past, from the seminal work of Tinto $(1975,1993)$ who investigated the reasons for student drop-out of university, to the more recent work of Kift \& Nelson (2005), Reason et al., (2007), Kift et al., (2010) who have investigated the "first year experience" as well as Christie (2009) who has investigated wider access or non-traditional student attrition. It is well known that academic ability alone is insufficient for success in the HE setting (Glogowska et al., 2007). For example, both formal and informal support networks, emotional intelligence, and other factors including resilience and the "will to learn" are all important for a successful and positive navigation of this important life transition (Parker et al., 2004; Barnett, 2007; Gale \& Parker, 2012).

Transition theory has indicated three separate stages namely: 1) transition as induction 2) transition as experience and 3) transition as becoming (Gale \& Parker, 2012; Kift et al., 2010). In the present study, we have investigated "transition as induction" as the first step towards the formation of a learning community. Transition induction activities can impact strongly on student perceptions of university life and are an important part of the first year experience at a time when new students have to navigate social and academic challenges related to the new learning environment or "habitus" (Bourdieu, 1986) with different modes and procedures (Parker et al., 2004; Yorke \& Longden, 2008; Currant \& Keenan, 2009). Recent research has indicated that student induction events remain very passive with beginning students receiving an overload of information, which can be overwhelming (Edwards, 2003; Wingate, 2007). 
In alignment with the theme of being future ready, there is current discourse in the literature calling for the need to use technologies more creatively, not only to support personalised student learning, but also to help develop graduate attributes that are required for agile learning throughout the life course (Selwyn, 2007, 2010; Ecclestone et al., 2010). Some previous studies have been conducted on the use of digital and webbased technologies to enable a more seamless transition to university (Currant \& Keenan, 2009). Lefever \& Currant (2010) reported on several approaches including the use of blogs, social networking and texting to support students undergoing transition (Harley et al., 2007). Currant \& Keenan (2009) recommended that new technologies should be used to foster the development of a supportive community which is particularly important in the first year experience in the HE setting. These authors report on a programme developed at the University of Bradford (UK), in which new students engaged with the university community prior to induction and undertook online modules designed to help them develop critical thinking skills, study skills, how to seek help and effectively "learn how to learn" (Currant \& Keenan, 2009; Barnett, 2007; Wingate, 2007).

Whilst some studies have shown success, there is much more scope for situating innovative technologies effectively in the HE setting and, in particular, technologies such as three dimensional virtual worlds which can support the development of learning communities, and also provide a space for meaningful learning to occur (Thomas \& Brown, 2009; Bronack et al., 2006; Dede, 2009). Since virtual worlds are web-based learning spaces, they can be visited either on or off campus, and they are persistent; meaning they are accessible 24 hours and 7 days a week, (24/7) and this can enhance the feeling of "belonging" amongst undergraduate students, as well as a feeling of "connectedness" with their university community.

\section{3-Dimensional Virtual Worlds in Higher Education}

The role of three-dimensional, immersive, avatar based virtual worlds has been investigated for learning in the HE setting (Bronack et al., 2006; Warburton, 2009; De Freitas et al., 2010a, 2010b; Savin-Baden et al., 2010). Hew and Cheung (2010) have conducted a review of virtual worlds such as Active Worlds ${ }^{\mathrm{TM}}$ and Second Life ${ }^{\mathrm{TM}}$ to support learning in HE settings, and found they were most frequently used in the subject domains of Media Arts and Health and Environment education (Hew \& Cheung, 2010). Mayrath et al., (2011) reported on "lessons learned" after integrating Second Life ${ }^{\mathrm{TM}}$ activities into an undergraduate English course. This study indicated a mixed response from students and highlighted the importance of pedagogy and context. Beaumont et al., (2012) evaluated a distributed, collaborative, problem-based learning project in an undergraduate health care setting which highlighted the importance of careful iterative design whilst Edirisingha et al., (2009) have illustrated the role of socialisation in the formation of a learning community within a group of undergraduate Archaeology students at the University of Leicester (UK). Warburton (2009) has highlighted some of the challenges and facilitators related to teaching and learning using virtual worlds in the HE setting, including technical and cultural issues. However, such novel virtual worlds in which learners or "participants" are embodied in the form of an avatar offer novel social learning opportunities, since the ability to walk, fly, interact with peers and work either alone or collectively along with the novel multi- media affordances and immersion in a visual 3-D environment rendered in real time is potentially a powerful tool for creative learning.

Most recently, Savin-Baden et al., (2010) have carefully considered the multi-media or multi-modal affordances of virtual worlds against the traditional "text" based or "written" world of Higher Education and scholarship. However, Jewitt et al., (2001) have reported on the multi-modal nature of the Science disciplines which have traditionally drawn on several semiotic representations in addition to text, namely: images, diagrams, models, symbols and experiences which all contribute to meaningful learning (Jewitt et al., 2001; Jewitt, 2006, 2008). The transfer of learning to digital spaces will draw on several technology tools and not just a mass migration to one space or environment, and it is essential that there is a portfolio of digital tools that can be tailored to student centred learning in HE settings. Increasingly, the transfer of learning to digital spaces will require the development of multi-modal literacies in order to navigate digital learning in a critical, responsible and informed manner (O'Halloran, 2012). Accordingly, there is a need for rigorous pedagogies and theories of learning to support and mediate learning in the HE setting with new Technology Enhanced Learning (TEL) tools (Laurillard, 2002).

\section{The "Inter-Life" Project}

The "Inter-Life" project is an interdisciplinary research project (see the web-site for more information at:

http://tel.ioe.ac.uk/inter-life; and the project video case study at: http://www.youtube.com/watch?v=21 xtQRxwTgg) that has successfully created two virtual world islands for young people to work creatively either individually or collaboratively on open or structured learning activities leading to the development of life transition skills including: resilience, self-confidence, team work and active problem-solving skills (Lally et al., 2009; Devlin et al., 2011, 2013; Lally \& Sclater, 2012). The Inter-Life virtual world islands are based on the Second Life ${ }^{\mathrm{TM}}$ platform but have been augmented with automated and unobtrusive data collection tools (Magill et al., 2009). The interdisciplinary Inter-Life team adopted a light touch, agile, participatory design approach and the project has created open spaces for meetings and learning activities which enable learner generated content as "digital transition tools", and also elective private spaces, called "Skyboxes" that were provided and equipped with a diary recording facility (similar to a virtual reflective journal) in order to foster reflection on learning carried out during creative learning experiences in Inter-Life (Magill et al., 2009; Devlin et al., 2012). "Inter-Life Island 1" (IL-I1) has been created for students ( $>18$ years of age) in order to provide a safe and supportive virtual environment for the formation of a learning community of students at the University of Glasgow (Magill et al., 2009; Devlin et al., 2012).

\section{Aim and Research Question}

The aim of the present study was to answer the following research question:

How effective is the innovative "Inter-Life" 3-dimensional virtual world (IL-I1) in supporting the initial stages of transition to university including peer-to-peer bonding, socialisation and the early stages of learning community formation through harnessing creative multi-media affordances to enable learners' ac- 
tive engagement and critical reflection to support learning about the post-transition world?

\section{Design of the Induction Event}

In order to answer this question, we designed two separate events which are depicted schematically in Figure 1. Firstly, a student mentors' "Inter-Life" training and orientation event in which post-transition (2nd - 4th year) Bachelor of Technological Education (B.Tech.Ed) students learned how to navigate and communicate in Inter-Life and learned about the aims and ethos of Inter-Life. The students had volunteered to act as virtual mentors to the new group undergoing transition to university. This was followed, a few months later, by the formal induction of a new cohort of B.Tech.Ed. students who were undergoing transition to the University of Glasgow.

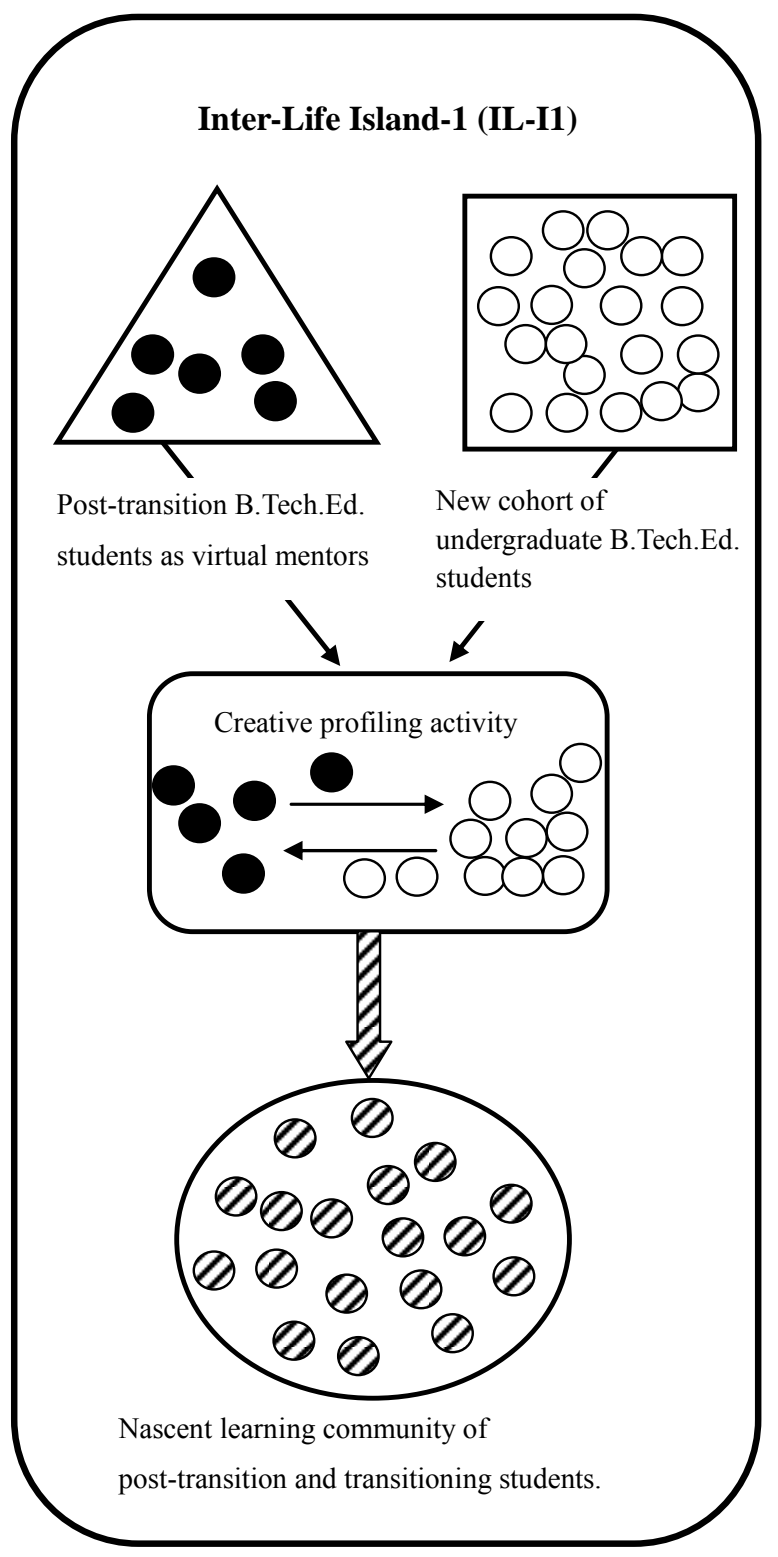

Figure 1.

Schematic representation of the design to foster a learning community.

\section{Pedagogy and Learning Theory}

The induction event was based on well established and rigorous theories of learning, including Kolb's theory of experiential learning (Kolb, 1984), which resonates with active learning pedagogy, since learning is an active process of assimilation by experience, and can take the form of an iterative learning cycle in which baseline knowledge and understanding is followed by active engagement in a learning activity and through negotiating challenges inherent in the activity, learning is accomplished then followed by reflection (Schön, 1983, 1991). The learning theorist Donald Schön has proposed reflection as a crucial aspect of professional learning and indeed it is a crucial tool for effective professional teaching practice. Schön (1991) has proposed "reflection on learning" as well as "reflection during learning", as being equally effective in enhancing professional practice in a responsive, reflexive fashion. It is significant that we wished to foster the development of critical reflection in the initial stages of active induction since the cohort of new students were undertaking the B.Tech.Ed. Degree programme to become teaching practitioners of technology education.

\section{Methodology}

The present study draws on Case study methodology since we have drawn on several sources of data (please see Table 1, below) to investigate a bounded event, namely the students experience of working in "Inter-Life" as a creative transitional active learning event (Yin, 2003). In keeping with Case study methodology, we sought to understand the learners' "lived experience" (Lincoln \& Guba, 1985) within this new virtual world setting within a socio-cultural, constructivist perspective and analytical lens.

We conducted a Focus group after the initial event with the "post-transition" B.Tech.Ed. student mentors (Table 1). With reference to Kolb's (1984) theory of learning and pedagogy, a baseline electronic questionnaire was distributed securely via "SurveyMonkey Inc." to the new undergraduate students in order to gather some basic demographic information, along with a series of questions about their previous use of and experience with technologies including three-dimensional virtual worlds.

This was followed up by the induction activity in "InterLife" which involved the students engaging with Inter-Life creating their avatar and participating in a creative profiling activity in which they prepared a personalised PowerPoint slide show for exhibiting and sharing amongst peers in the student profile hall building in Inter-Life. The profile task involved choosing an animal image as a metaphor to represent "self" in an anonymous manner (Goffman, 1959; Dweck, 1999). The other four slides conveyed some basic background information in response to captions:

1) Choose an animal image as creative metaphor of "self";

2) Who am I?

3) What do I like?

4) Why am I here (at university)?

5) Three additional things that you should know about me.

This task was modelled by the tutors and the students were provided with handouts in order to guide them through the steps involved in creating their display in the virtual student 
profile gallery building. In order to lower the threshold of sharing information about "self" and to foster a safe and equitable activity, the new students shared a generic first name for their avatar (Neptune) but were allowed to choose a unique surname. Thus, all the new students were named Neptune, and similarly the post-transition virtual mentors shared the same first name of Jupiter. One new student was a direct entry into second year and had the first name of Saturn. This served to delineate who was a mentor and who was a new student, whilst the tutors/ researchers had unique avatar names. This was implemented in order to provide a degree of anonymity in the initial stages of the induction. The final stage (Kolb, 1984) involved all of the students "rezzing" their individual private Skybox and completing a reflection on the activity in response to reflective prompts. In addition, there was a follow-up focus group with students who had participated, approximately one week after the event, in order to gather more feedback. Table 1, below summarises the data collected.

Table 1.

Summary of data collected.

\begin{tabular}{cc}
\hline Methodology & Number \\
\hline B.Tech.Ed. Mentors' Focus Group & $\mathrm{n}=7$ \\
E-questionnaire to new B.Tech.Ed. students & $\mathrm{n}=36$ \\
Inter-Life interactive profile displays & $\mathrm{n}=24$ \\
Inter-Life reflective journal episodes & $\mathrm{n}=24$ \\
Post Inter-Life Focus Group & $\mathrm{n}=4$
\end{tabular}

\section{Ethics}

Full ethical approval for the present study was obtained in advance by the University of Glasgow, School of Education Ethics Committee.

The University of Glasgow, School of Education works in alignment with ethical guidelines outlined by BERA and the ESRC. All appropriate procedures, including fully informed consent and anonymisation of datasets were undertaken.

\section{Data Analysis}

In order to facilitate data management and analysis all datasets were uploaded into QSR NVivo 8. Focus groups were digitally recorded and transcribed verbatim and anonymised to protect participants' identity. The results from the baseline electronic questionnaire ("SurveyMonkey Inc.") were analysed in Excel. The student multi-modal profile displays were analysed for emergent themes and units of meaning were mapped to nodes in NVivo 8. Open coding of units of meaning were mapped to nodes firstly for individual presentations then cluster analysis and formal coding was conducted across all student profile displays to identify the frequency of emergent themes (Miles \& Huberman, 1994). The nodes with the most frequent coding were synthesised within the results section, and illustrative units of meaning are presented (Lincoln \& Guba, 1985). The student text based reflective episodes were analysed for word count as an initial approach to extent of reflection, then analysed thematically for overall perception of the activity and criticality of understanding of the Inter-Life virtual world for learning and in order to answer the research question (Devlin et al., 2013). The overall perception of the event was coded according to four emergent responses, which are summarised in Table 4 in the Results section.

The clustering of emergent themes was conducted to nodes that were composed from participants' perceptions to form "units of meaning" and the data was coded appropriately to each node (Cresswell, 2009). Representative excerpts of qualitative data from focus groups and reflective episodes were then presented to illustrate the depth and variety of critical reflection on learning and the activity.

\section{Results}

The student mentors' focus group indicated that the InterLife training and orientation workshop was well received by the 2nd - 4th year B.Tech.Ed. students. Although the student mentors had extensive ICT experience including programming skills and designing "patches" for Games, very few of them had prior experience of working in immersive virtual worlds. However, importantly the students recognised that Inter-Life was not a pre-scripted Gaming environment and that participants are free to work alone or collaborate with peers in this new virtual world space. Some of the students had prior experience with other virtual platforms such as "The Sims":

"I play The Sims a lot at home [....] eh, and I wanted to see how similar it was to that...in that it is other people who are controlling their own characters and to see how they interact with you rather than just the computer getting what you want it to do." 4th year student (Mentors' Focus Group)

The B.Tech.Ed. mentors also recognised the potential for creative engagement and communication both within and between year group on the B.Tech.Ed. Degree programme whether on or off campus and the potential for the development of a community:

"[..........but em I would envisage almost creating almost a community of former and present BTechEd students within this sort of environment that can act as an ongoing basis as mentors and provide help for BTech Ed...(students)." 3rd year student (Mentors' Focus Group)

Other feedback included the mentors' appraisal of the InterLife platform as being accessible and a non-threatening environment in which to mix with and learn from peers and tutors:

\begin{abstract}
"Because it could be quite daunting if you are in first year and you think...I want to ask a fourth year a question, but do I send somebody I don't really know an e-mail? Whereas if you are on Inter-Life, ...[...] it would be a lot easier to chat to them and ask stuff... It keeps it a bit more comfortable..." 3rd year student (Mentors' Focus Group)
\end{abstract}

Therefore, the student mentors recognised the potential for a learning community and saw Inter-Life as a flexible place to meet and interact with fellow students and tutors. The students all understood their role as virtual mentors, welcoming and meeting and greeting the new student cohort on induction day.

\section{Student Induction Event}

The response to the new undergraduate student questionnaire 
issued at the start of the student induction day showed that the new class $(n=36)$ was composed of $19(53 \%)$ males and 17 (47\%) females (Figure 2(a)) and most of the students were under 20 years of age (Figure 2(b)). Although the students had extensive experience of ICTs, the majority of the class $(n=31$; $86 \%$ ) had never worked with virtual world platforms before. In keeping with ethical procedures for IL-I1, only those students who were over 18 years of age $(n=28)$ participated in the creative profiling activity in Inter-Life.

\section{Class according to gender}

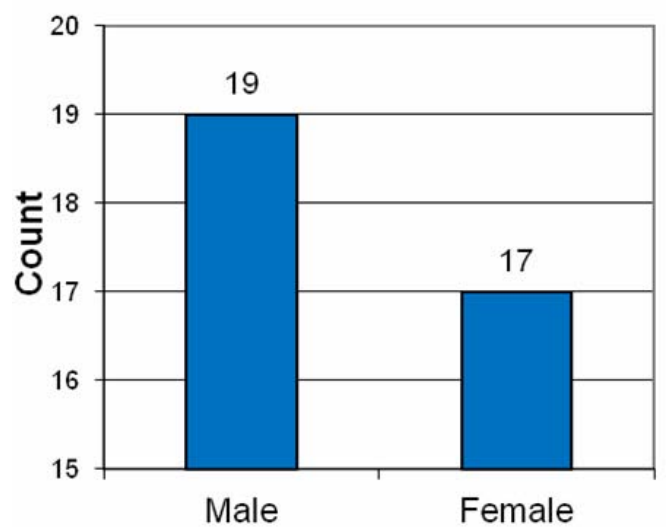

(a)

\section{How old are you?}

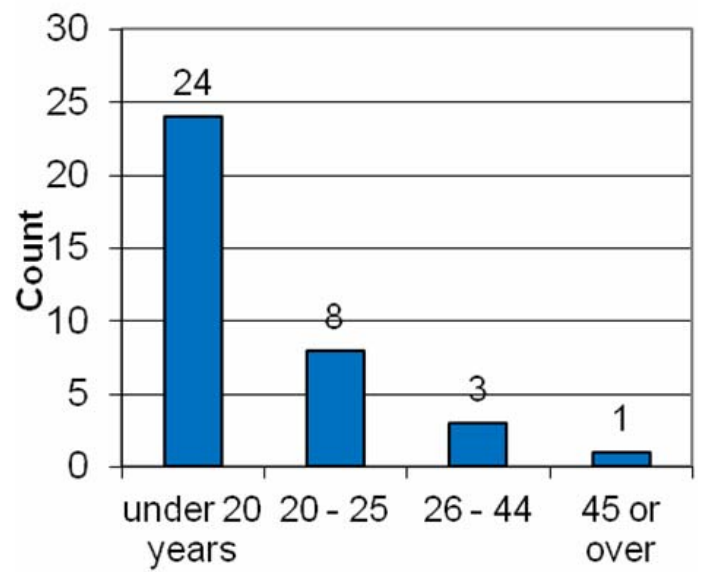

(b)

Figure 2.

(a) The new student cohort according to gender; (b) The new student cohort according to age.

The students prepared highly creative, multi-modal and personalised profiles which were exhibited in the student virtual profile hall building in Inter-Life. Figure $\mathbf{3}$ is a screenshot which illustrates the variety of animal images chosen as a "metaphor of self" by the new student cohort (Goffman, 1959).

Such rich multi-modal profiles represent a "mini-portrait" of each student and this activity was designed to support the students in reflecting on their reasons for coming to university, including the acknowledgement and value of their previous education and skills and also to support them in learning about their peers' interests and experiences, and their hopes for the new course and the future (Schön, 1983). As such, this resulted in a very rich learning space in the student profile hall for the new students to share and interact with their peers and mentors via their profiles.

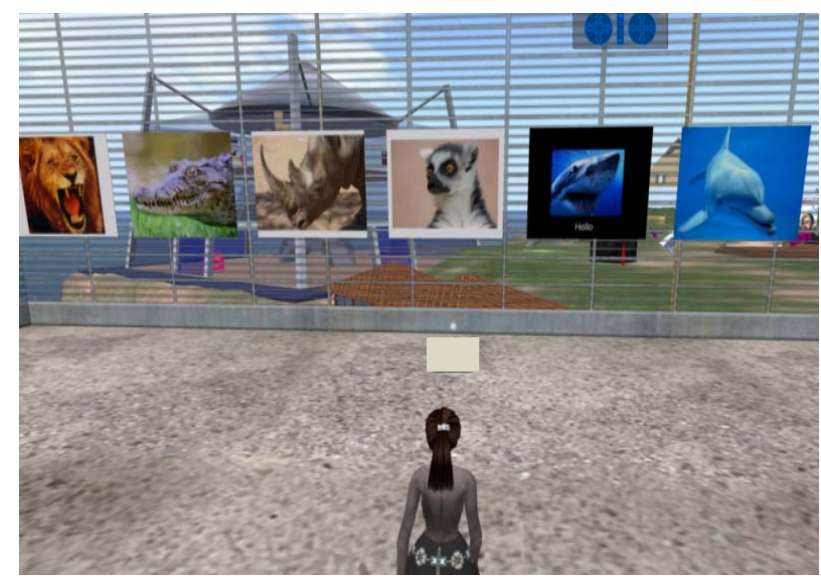

Figure 3.

A screenshot taken inside the student Profile Hall in Inter-Life Island 1 (IL-I1).

Although a significant proportion of the new cohort of students had come via the traditional route of school into university there were some mature students who were entering HE from industry or other careers (Figure 4).

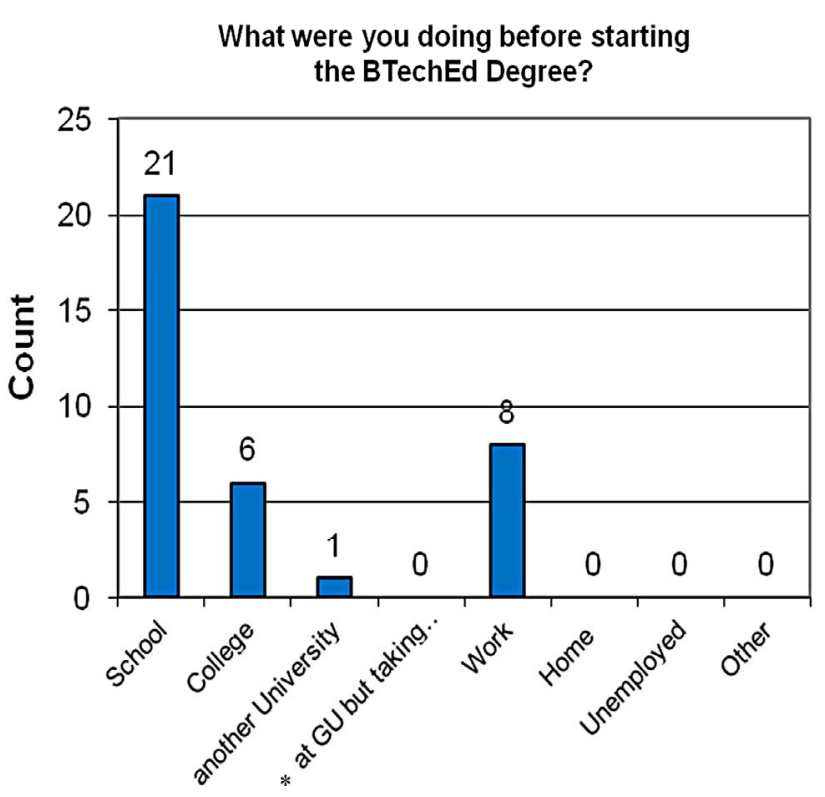

Figure 4.

Where the new student cohort had come from. "Fourth category from the left truncated; should read "at GU (University of Glasgow) but taking another Degree programme".

In keeping with the "fragmented" nature of 21st Century students, a number of the boards showed that the students were used to working part time and/or also held FE qualifications (Leese, 2010). Figures 5(a) and (b) show representative screenshot examples of student profile boards. 


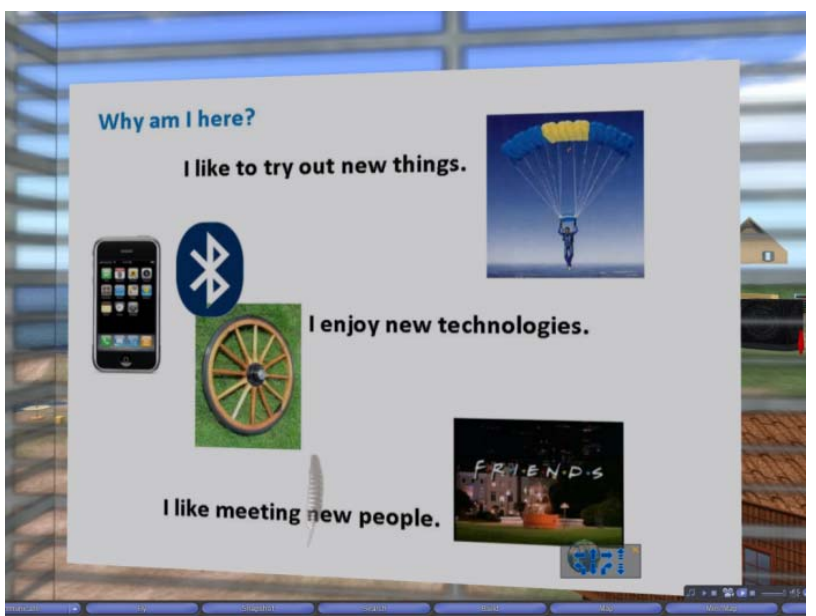

(a)

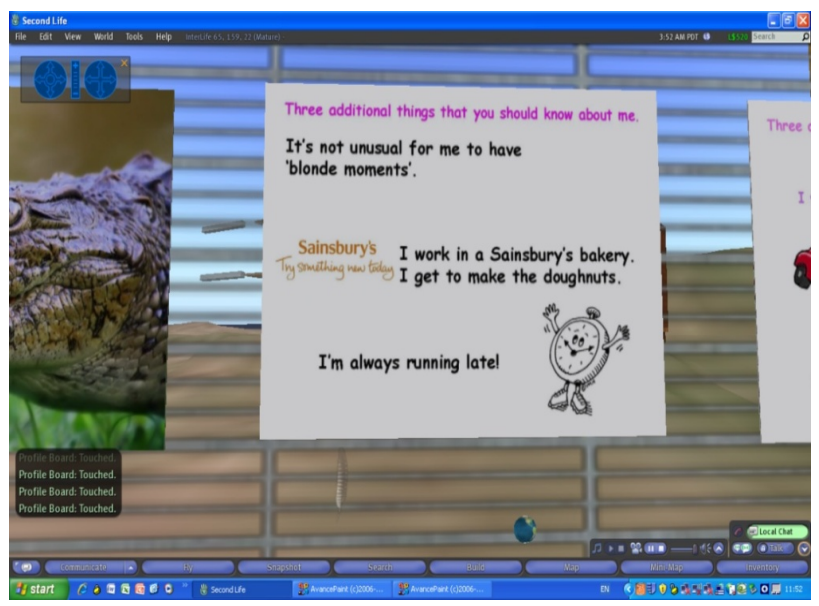

(b)

Figure 5.

(a) Screenshot showing an example of a student profile display; (b) Screenshot showing an example of a student profile display.

The majority of the class ( $\geq 18$ years old) completed the creative profiling activity. Analysis of the profile boards showed that the students converged in their likes and their reasons for coming to university, which clustered around the main themes as presented in Table 2 .

Table 2.

Thematic summary of student profile displays.

\begin{tabular}{ll}
\hline \multicolumn{1}{c}{ What I like } & \multicolumn{1}{c}{ Why am I here } \\
\hline Favourite sports/interests & Desire to learn and develop their skills further \\
Favourite music/bands & Enjoyment and interest in their subject \\
Favourite holidays/travel & Desire to influence their future career \\
Travel experiences & Desire to work with and help young people \\
Friends and family & Desire to meet new (like-minded) people \\
\hline
\end{tabular}

The students used a highly personalised and creative combination of images, signs, art and text in their interactive PowerPoint slide displays. Some representative extracts of the text presented in the profile boards include:

\section{"I want to influence the future of Design and Technology Education.” Jupiter Crannock (Mentor)}

"To achieve my goal in this career." Neptune Lemondrop (New student)

The "three additional things you should know about me" slides included the strong use of humour and also included interesting and significant reflections on previous life experiences:

"I work as a barman in a 'Brewer's Fayre' restaurant and yes, I have to dress up as the bear...” (Neptune Haiku)

"I have an HND in Interior Design. I can play and write my own music for piano and guitar..." (Neptune Erin)

\section{"I am a third time Fresher!" (Neptune Mhia)}

The profile displays are learner generated social learning objects which are examples of multi-modal literacy (O'Halloran, 2012). However, a multi-modal analysis of the complete set of "in-world" student profile displays will form the basis of a future article.

After participating in the active profiling activity in the student profile hall, the students then gathered at the Skybox rezzer and teleporter then each rezzed their own Skybox and Figure 6 shows a screenshot taken while the new student group were working near the "teleporter" in "Inter-Life".

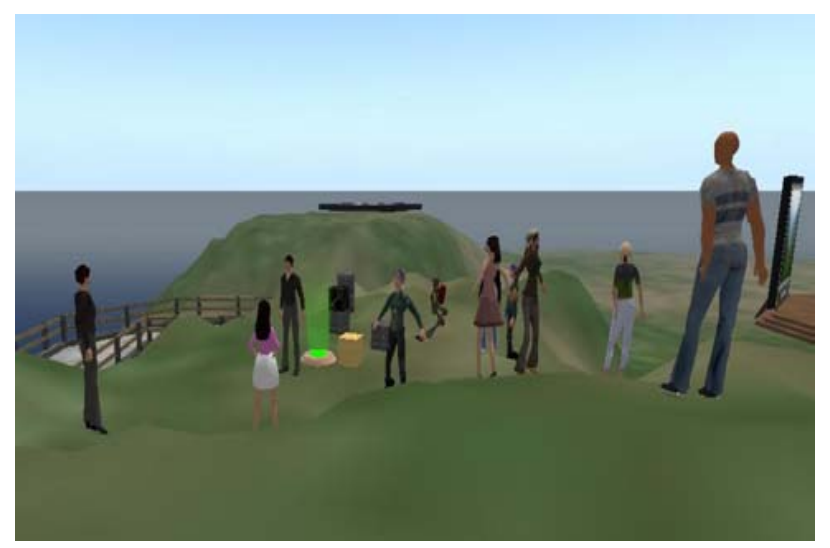

Figure 6.

Screenshot showing new students working in "Inter-Life".

The last stage of the students' activity was to teleport to the Skybox and complete their first reflective episode which they recorded using the diary text recording facility in their own individual private Skybox. The reflective prompts (Schön, 1983) that we asked the students to consider were:

1) Please spend a little time now discussing your thoughts on the content of your profile board and why you chose to include the content that you did.

2) Did you find other profile boards interesting and useful in allowing you to get to know the other students?

3) How did it feel when you were considering which information you wished to allow others to know about you?

Figure 7 shows a screen shot of a private Skybox in the air space of IL-I1 with the outer walls of neighbouring Skyboxes 
visible in the background.

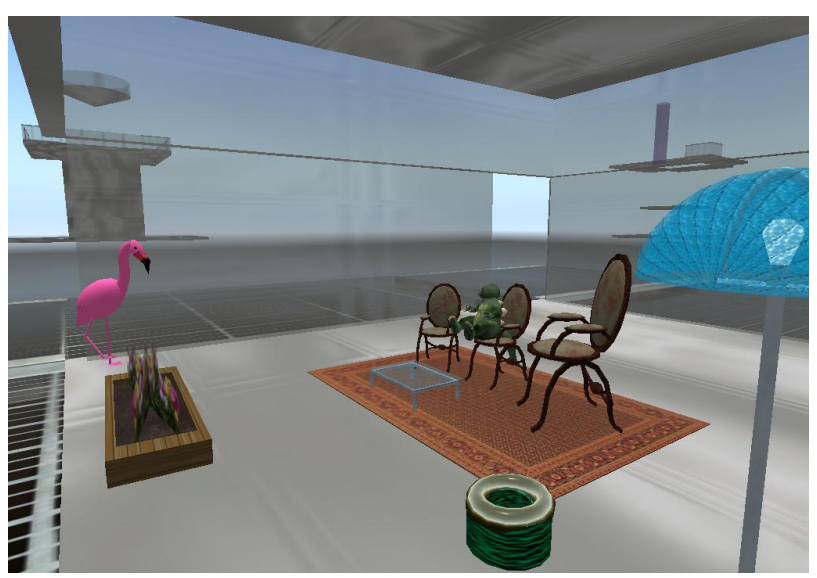

Figure 7.

Screenshot of inside a student Skybox.

The reflective logs varied in length from a few sentences to extensive rich and critical reflections. Please see Table 3 which summarises the word count of the students' reflective episodes.

Table 3.

Word count summary of student reflective episodes.

\begin{tabular}{|c|c|c|}
\hline Reflective log & Name & No. of words \\
\hline 1 & Neptune Soup & 8 words \\
\hline 2 & Neptune Cristole & 174 words \\
\hline 3 & Neptune Endrizzi & 4 words \\
\hline 4 & Neptune Broono & 199 words \\
\hline 5 & Neptune Scientist & 74 words \\
\hline 6 & Neptune Darkmatter & 13 words \\
\hline 7 & Neptune Foxdale & 115 words \\
\hline 8 & Neptune Crystal & 25 words \\
\hline 9 & Neptune Mint & 52 words \\
\hline 10 & Neptune Bonham & 10 words \\
\hline 11 & Neptune Mhia & 123 words \\
\hline 12 & Neptune Crumb & 85 words \\
\hline 13 & Saturn Mistwalker ${ }^{*}$ & 215 words \\
\hline 14 & Neptune Erin & 155 words \\
\hline 15 & Neptune Inkpen & 337 words \\
\hline 16 & Neptune Haiku & 260 words \\
\hline 17 & Neptune Lemondrop & 45 words \\
\hline 18 & Neptune Petrolhead & 101 words \\
\hline 19 & Neptune Kamala & 34 words \\
\hline 20 & Neptune Texan & 177 words \\
\hline 21 & Neptune Admiral & 75 words \\
\hline 22 & Neptune Melody & 6 words \\
\hline 23 & Neptune Jovinavic & 20 words \\
\hline 24 & Neptune Endsleigh & 21 words \\
\hline
\end{tabular}

*Saturn was a direct entrant into second year.

The students' reflective journal entries showed that the majority of the new cohort found the induction event innovative, interesting and stimulating (please see Table 4). The "virtual" journal entries provided evidence of reflection about "self" and identity as explored through the profile slides (Sfard \& Prusak, 2005). Coding of the reflective episodes was conducted and is summarised in Table 4 . The majority (75\%) of the new students found the induction activity meaningful and helpful and understood how it contributed to self-regulated learning:

"I have enjoyed taking part in this process and I think it is a good start to the year, showing some technology, as well as developing personally..." Reflective Learning Log (Neptune Scientist)

There was also evidence of critical "reflection on learning" as a result of experience:

"At first I was unsure and sceptical about the aim of this exercise, however, after completing my profile and having the chance to read others, I found it very interesting! Creating my profile made me think about how I may be perceived by others and how I'd want to be perceived...however, you are not aware of who you are actually talking to and so still don't really know many people." Reflective Learning Log (Neptune Mhia)

"The contents boards were a good way to convey the type of person I am. I chose the Dolphin picture to show that I am friendly and helpful. All of the content I chose for my profile boards relate to me at present. They show what I am interested in...what matters to me....my intentions for this course and a few facts about my life at present. This was a good way for others to see what I am like. It also gave me the opportunity to glance at other people's interests and facts." Reflective Learning Log (Neptune Erin)

Most of the students $(n=18)$ were "positive" or "very positive" about the activity overall and were proficient in the use of the new media affordances in Inter-Life. However, some of the students remained neutral $(n=4)$, whilst a few $(n=2)$ struggled to engage with or relate to, the virtual world (please see Table 4).

Table 4.

Reflective episode analysis.

\begin{tabular}{ccc}
\hline Category & Count & Percentage of total \\
\hline Very positive & 7 & $29 \%$ \\
Positive & 11 & $46 \%$ \\
Neutral & 4 & $17 \%$ \\
Negative & 2 & $8 \%$ \\
Total & 24 & $100 \%$ \\
\hline
\end{tabular}

In order to investigate this further we carried out a post-induction Focus Group approximately one week after the event. The "follow-up" Focus Group revealed some further feedback and student recommendations for the future including the need for more training in the functional and social skills required for learning in Inter-Life:

"I somehow, accidentally deleted my hair! I put a hat on then took it off and it took my hair with it..!" New (young) undergraduate B.Tech.Ed student

The students also varied in their proficiency in virtual world skills required to function, navigate and communicate effectively in Inter-Life, and one (mature) student commented:

“...And eh, not being as Computer literate as a lot of the 
younger ones...em I just felt "For goodness sake, what is happening here?" New (mature) undergraduate B.Tech.Ed student

The students reported the need for a more step-wise introduction to Inter-Life and more training in the functional skills required. They also recommended the introduction of some modules on Inter-Life into the B.Tech.Ed. Degree programme or alternatively to locate some course assignments in the InterLife virtual world. Finally, some students expressed a preference for a more blended approach to induction in the future namely; to include an element of face-to-face activity as well as working within the Inter-Life virtual world.

\section{Discussion}

The present study was designed to investigate the effectiveness of Inter-Life Island 1 (IL-I1) as a novel technology enhanced learning (TEL) tool to help with the initial stages of transition to university (Magill et al., 2009; Devlin et al., 2012). In particular, we wished to determine the effectiveness of the IL-I1 three-dimensional virtual world and its novel multi-media affordances in supporting early peer-to-peer bonding, active learning, socialisation and the initial steps of formation of a learning community.

From a technical perspective, the student induction proceeded with few delays and the avatar positional tracking and associated text gathering features were automatically logged in the private and secure back end Server. Similarly, Inter-Life successfully hosted up to 35 participants simultaneously "in-world" ("in-world" means in the Inter-Life virtual world) including the virtual mentors and tutors, which demonstrates the robustness of the technical design (Magill et al., 2009). In addition, all of the student Skyboxes were rezzed successfully and the private diary recording feature worked for all student Skyboxes.

This is an important point to emphasise, since our previous studies were conducted with smaller groups of younger learners $(<18$ years of age) on Inter-Life Island 2 (IL-I2) albeit over a longer period of time (Devlin et al., 2011, 2013; Lally \& Sclater, 2012 , 2013). The present study has demonstrated the functionality of IL-I1 and the suitability of the Inter-Life islands for supporting larger student groups engaged in learning simultaneously. Therefore it provides important evidence to support the flexibility of such virtual world spaces for learning.

We wished to investigate whether Inter-Life would support an active induction drawing on its novel multi-modal affordances in order to create learner-generated transition tools, which would help mediate transition into the university community and also help with development of 21 st Century graduate skills (Ecclestone et al., 2010).

The activity involved the creation of individual and highly personalised profiles by new students, as well as the virtual mentors in order to foster socialisation as one of the first steps towards formation of a supportive learning community (Minocha \& Roberts, 2008; Edirisingha et al., 2009; Wenger, 1998). This activity resulted in a visually rich profile hall with creative multi-modal, "mini-portrait" interactive slide shows about "self" (Goffman, 1959). Since this was "learner-generated" and persistent (i.e., available 24/7) content, it enabled the concurrent development of meaningful transition tools with increasing learner autonomy, and was designed to foster a sense of ownership amongst the B.Tech.Ed. student group. It also enabled efficient viewing of up to 28 personalised and unique 3-dimensional mini-profiles in contrast to the possible alternative faceto-face linear presentations by the new student cohort which would have been much more time consuming. Therefore, virtual worlds have the potential for creative, efficient new learning and teaching processes and practices, but such innovation was undoubtedly related to the interdisciplinary nature of the Inter-Life research team. Such multi-modal semiotic resources represent examples of multi-modal literacy afforded by new digital technologies which enable creative expression through image, symbols and text which all contribute to deep meaning making (Kress, 2003; Jewitt et al., 2001; Jewitt, 2006, 2008; O'Halloran, 2012). Multi-modal digital analysis of 3-dimensional social learning objects is a newly emerging field which O'Halloran (2012) has written about recently, and 3-dimensional virtual worlds and their social learning objects represent ideal spaces for visual multi-modal communication and expression.

Although the majority of the students were positive about the activity and indicated it was worthwhile, the feedback also indicated a somewhat mixed response. Interestingly, some students carried out "reflection during learning" and actively reconfigured their response from an initial negative to a more positive understanding of what the activity was designed to achieve. This shows how effective Inter-Life was in supporting both "reflection during learning" and "reflection on learning" (Schön, 1983, 1991). In addition, the majority of the students engaged with the reflective learning episode in contrast to an earlier study by Seale \& Cann (2000) in which few students engaged with reflection in an online learning environment (Seale \& Cann, 2000). The use of technologies to effectively foster the skill of critical reflection and community development in online settings has become of increasing importance, and especially in student teacher education (Yang, 2009).

However, some of the students struggled to understand or relate to the virtual world. This is in keeping with a previous study by De Freitas et al., (2010) who found that older learners struggled to engage with a virtual world platform. Savin-Baden et al., (2010) have also recently reflected on the "steep learning curve" that exists for teaching and learning in 3-dimensional virtual worlds in the HE setting. The findings from the present study also resonates with the ongoing debate on 21 st Century students as "digital natives" (Bennett et al., 2008) and underscore the crucial role of pedagogy and learning design for TEL that is "situated" in a meaningful context (Laurillard, 2002). It does not necessarily follow that students as consumers of digital technologies informally will be able to adapt to the critical application and meaningful engagement with TEL tools in more formal educational settings (Luckin et al., 2009).

It is also noteworthy that the students were beginning their studies to become teachers of technological education. In an earlier study conducted with pre-service education student teachers in Australia, Campbell (2009) implemented a step-wise training procedure in virtual world navigation and communication skills which was integrated and assessed as part of the degree programme. The pre-service teachers successfully designed lessons and learning activities in a virtual world for their prospective pupils and reported that they would use virtual world technologies in their future teaching career, but they also felt constrained by the lack of access to 3-dimensional virtual world platforms in schools. This issue with access and integration in schools is reflected in separate findings in the UK (Merchant, 2010). It is interesting to speculate that if such vir- 
tual worlds were integrated into the contemporary school learning environment then pupils transitioning into HE settings may engage more readily with such digital learning environments, but this would form the basis of research into future generations of transitioning students.

Savin-Baden et al., (2010) have reported on the necessity for iterative reflective agile design involving the learners. Similarly, Oliver (2013) has recently written on theorising the technology enhanced tools that we use, or in the case of "Inter-Life" the tools we have created through interdisciplinary participatory research. Importantly, our recent studies as part of the "InterLife" project have attempted to "theorise" the new TEL tools we have created (Lally \& Sclater, 2012; Devlin et al., 2013). Accordingly, the Inter-Life project adopted participatory design from the outset and included open ended and structured learning activities to provide a space for meaningful learning to occur (Devlin et al., 2013). Although the present study reports on a more "choreographed" initial learning activity, it was carefully planned to enable personalisation and active learning and its aims were similar in fostering engagement through the creation of a meaningful supportive space for learning from a sociocultural, constructivist perspective and also drawing on Community of Practice theory (Wenger, 1998).

The present study illustrates the important synergy between the "design" of TEL tools and rigorous learning theories and pedagogies that, when implemented effectively, can migrate learning into a new virtual world setting. Such digital agility is an important feature of 21 st Century learning and teaching in the HE setting (Biesta, 2011; Littlejohn et al., 2012). We suggest that virtual worlds are an effective new tool to support meaningful learning, but which must be implemented judiciously and in a critical and informed fashion in order to exploit their potential for creative and meaningful learning.

In future iterations of Inter-Life, and in keeping with results from the current study, it may be beneficial to conduct a longerterm series of training modules on basic skills acquisition and/ or locate some of the B.Tech.Ed. course activities in the Inter-Life virtual world. Such iterative design is in keeping with previously reported studies (Beaumont et al., 2012; Mayrath et al., 2011).

However, the present study has provided some new evidence to suggest that the Inter-Life virtual world islands represent new socio-cultural and flexible learning tools that can support learning in the HE setting, which adds to our previous studies conducted with younger learners (Devlin et al., 2011, 2013; Lally \& Sclater, 2012, 2013). The novel features of embodiment and co-presence along with the multi-media affordances and the visual nature of the environment also appeal to different learning styles (Devlin et al., 2013).

Importantly, the rigorous pedagogical design implemented in Inter-Life involved learner generated transition tools in order to foster active and reflective learning behaviours (Yang, 2009; Seale \& Cann, 2000) as well as self-regulated learning. However, the transitioning students recommended a more step wise introduction to Inter-Life and they also recommended a more blended approach to induction in the future, namely an element of working face-to-face as well as working in the Inter-Life virtual world.

This empirical research study is significant since it has demonstrated the rigour of the pedagogical design which was a key aspect in the overall success of the transition event. Such critical pedagogy is essential when investigating new TEL tools for meaningful learning (Laurillard, 2002). Furthermore, the present research is significant since it extends transition theory in keeping with 21 st Century students, who are frequently connected via mobile and other digital devices in order to manage their studies whilst on or off campus in keeping with the fluid and somewhat "fragmented" nature of contemporary student life (Leese, 2010). The present study extends transition theory by identifying a new strand of "virtual transition" through students participating meaningfully in a personalised virtual university community. The careful design of Inter-Life enabled new undergraduate students to:

1) establish contacts with B.Tech.Ed. students who are already in the "post-transition" HE setting;

2) experience some peer support and communicate with new groups;

3) develop the learning skill of critical reflection (Brockbank \& Magill, 1998).

The findings from the present study provide some further empirical evidence to support the rigour of the technical and educational design of the Inter-Life virtual worlds (Magill et al., 2009; Devlin et al., 2012, 2013). In this study we have demonstrated the role of IL-I1 in supporting young people (of $\geq 18$ years of age) undergoing transition to university through creative learning activities. However, the findings also present some evidence to contest the notion of "digital natives" which is in keeping with the current literature in the field (Bennett et al., 2008; Helsper \& Eynon, 2010; Kennedy et al., 2010).

Finally, we have provided some new evidence to support the effectiveness of immersive education in the HE setting and it is likely that virtual immersive worlds, such as Inter-Life can be tailored to learning in or across the cognate disciplines in the HE setting. Furthermore, because virtual immersive worlds are web based, they can support distributed communities of learners in the HE setting, locally or indeed globally. In conclusion, virtual worlds have potential for supporting distributed learning and as such, are an important and valuable TEL tool, both locally and globally for universities in the 21 st Century.

\section{Acknowledgements}

We wish to thank the B.Tech.Ed. students from the School of Education, University of Glasgow who volunteered to participate as virtual student mentors in the "Inter-Life" project. We also wish to thank all of the B.Tech.Ed. students who were in the new cohort undergoing transition to the University of Glasgow and who participated in the "Inter-Life" project.

Dr. Alison M. Devlin is lead author of this article.

The "Inter-Life" project was funded by EPSRC/ESRC(UK) RES-139-25-0402.

\section{REFERENCES}

Barnett, R. (2007). A will to learn: Being a student in an age of uncertainty. McGraw-Hill/Open University Press.

Bennett, S., Maton, K., \& Kervin, L. (2008). The "digital natives" debate: A critical review of the evidence. British Journal of Educational Technology, 39, 775-786. doi:10.1111/j.1467-8535.2007.00793.x

Beaumont, C., Savin-Baden, M, Conradi, E., \& Poulton, T. (2012). Evaluating a second life problem-based learning demonstrator project: What can we learn? Interactive Learning Environments, 1-17. doi: $10.1080 / 10494820.2011 .641681$

Biesta, G. J. J. (2011). How useful should the university be? On the rise of the global university and the crisis in higher education. Qui Parle: 
Critical Humanities and Social Sciences, 20, 35-47.

Bourdieu, P. (1986). "The forms of capital". Handbook of theory and research for the sociology of capital. New York: Greenwood Press.

Brockbank, A., \& McGill, I. (1998). Facilitating reflective learning in higher education. Buckingham: Society for Research in Higher Education and Open University Press.

Bronack, S., Riedl, J., \& Tashner, J. (2006). Learning in the zone: A social constructivist framework for distance education in a 3-dimensional virtual world. Interactive Learning Environments, 14, 219232. doi:10.1080/10494820600909157

Campbell, C. (2009). Learning in a different life: Pre-service education students using an online virtual world. Journal of Virtual Worlds Research, 2, 4-17.

Christie, H. (2009). Emotional journeys: Young people and transitions to university. British Journal of Sociology of Education, 30, 123-136. doi:10.1080/01425690802700123

Cresswell, J. (2009). Research design: Qualitative, quantitative and mixed methods approaches (3rd ed.). New York: Sage.

Currant, B., \& Keenan, C. (2009). Evaluating systematic transition to higher education. The Brookes Ejournal of Learning and Teaching, 2, 4.

http://bejlt.brookes.ac.uk/article/evaluating_systematic_transition_to higher_education/

Dède, C. (2009). Immersive interfaces for engagement and learning. Science, 323, 66-68. doi:10.1126/science.1167311

De Freitas, S., Rebolledo-Mendez, G., Liarokapis, F., Magoulas, G., \& Poulovassilis, A. (2010). Learning as immersive experiences: Using the four dimensional framework for designing and evaluating immersive learning experiences in a virtual world. British Journal of Educational Technology, 41, 69-85.

doi:10.1111/j.1467-8535.2009.01024.x

De Freitas, S., \& Veletsianos, G. (2010). Editorial: Crossing boundaries: Learning and teaching in virtual worlds. British Journal of Educational Technology, 41, 3-9. doi:10.1111/j.1467-8535.2009.01045.x

Devlin, A. M., Lally, V., Sclater, M., \& Parussel, K. (2011). The development of life transition skills in Inter-Life: A novel, 3-dimensional virtual learning environment. In H. Spada, G. Stahl, N. Miyake, \& N. Law (Eds.), Connecting Computer-Supported Collaborative Learning to Policy and Practice: CSCL 2011 Conference Proceedings, II, 874-875.

Devlin, A. M., Canavan, B., Magill, J., \& Lally, V. (2012) Evaluation of the novel Inter-Life virtual world as an innovative technology to support transition to University. European Conference on Educational Research (ECER), University of Cadiz, 18-21 September 2012.

Devlin, A. M., Lally, V., Sclater, M., \& Parussel, K. (2013). Inter-life: A novel, three-dimensional, virtual learning environment for life transition skills learning. Interactive Learning Environments, iFirst Article. doi:10.1080/10494820.2013.768271

Dweck, C. (1999). Self-theories: Their role in motivation, personality and development. Philadelphia, PA: Psychology Press.

Ecclestone, K., Biesta, G., \& Hughes, M. (2010). Transitions and Learning throughout the life course. Routledge: London \& New York.

Edirisingha, P., Nie, M., Pluciennik, M., \& Young, R. (2009). Socialisation at a distance in a 3-D multi-user virtual environment. British Journal of Educational Technology, 40, 458-479. doi:10.1111/j.1467-8535.2009.00962.x

Edward, N. S. (2003). First impressions last. An innovative approach to induction. Active Learning in Higher Education, 4, 226-242. doi: $10.1177 / 14697874030043003$

Facer, K., \& Sandford, R. (2010). The next 25 years? Future scenarios and future directions for education and technology. Journal of Computer Assisted Learning, 26, 74-93. doi:10.1111/j.1365-2729.2009.00337.x

Gale, T., \& Parker, S. (2012). Navigating change: A typology of student transitions in Australian higher education. Studies in Higher Education, iFirst Article. doi:10.1080/03075079.2012.721351

Glogowska, M., Young, P., \& Lockyer, L. (2007). Should I stay or should I go? A study of factors influencing students' decisions on early leaving. Active Learning in Higher Education, 8, 63-77. doi:10.1177/1469787407074115

Goffman, E. (1959). The presentation of self in everyday life. New York: Doubleday.

Harley, D., Winn, S., Pemberton, S., \& Wilcox, P. (2007). Using texting to support students' transition to university. Innovations in Education and Teaching International, 44, 229-241. doi: $10.1080 / 14703290701486506$

Helsper, E., \& Eynon, R. (2010). Digital natives: Where is the evidence? British Educational Research Journal, 36, 503-520. doi: $10.1080 / 01411920902989227$

Hew, K. F., \& Cheung, W. S. (2010). Use of three-dimensional (3-D) immersive virtual worlds in K-12 and higher education settings: A review of the research. British Journal of Educational Technology, 41, 33-55. doi:10.1111/j.1467-8535.2008.00900.x

Jewitt, C., Kress, G., Ogborn, J., \& Tsatsarelis, C. (2001) Exploring learning through visual, actional and linguistic communication: The multimodal environment of a science classroom. Educational Review, 53, 5-18.

Jewitt, C. (2006). Technology, literacy and learning: A multimodal approach. London: Routledge.

Jewitt, C. (2008). Multimodality and Literacy in school classrooms. Review of Research in Education, 32, 241-267. doi:10.3102/0091732X07310586

Kennedy, G., Judd, T., Dalgarno, B., \& Waycott, J. (2010). Beyond natives and immigrants: Exploring types of net generation students. Journal of Computer Assisted Learning, 26, 332-343. doi:10.1111/j.1365-2729.2010.00371.x

Kift, S., \& Nelson, K. (2005). Beyond curriculum reform: Embedding the transition experience in Higher Education in a changing world. Proceedings of the 28th Higher Education Research and Development Society of Australia (HERDSA) Annual Conference (pp. 225 235), Sydney, 3-6 July 2005.

Kift, S., Nelson, K., \& Clarke, J. (2010). Transition pedagogy: A third generation approach to FYE - A case study of policy and practice for the higher education sector. The International Journal of the First Year in Higher Education, 1, 1-20.

Kolb, D. A. (1984) Experiential learning: Experience as a source of learning and development. Englewood Cliffs, NJ: Prentice-Hall, Inc.

Kress, G. (2003). Literacy in the new media age. London: Routledge. doi: $10.4324 / 9780203164754$

Lally, V., Magill, E., Magill, J., Canavan, B., Kolberg, M., Pomerantz, M. et al. (2009). Inter-Life: Inter-operability and transition. Paper Presented at CAL09-Learning in Digital Worlds conference, Brighton, UK.

Lally, V., \& Sclater, M. (2012). The Inter-Life project: Inter-cultural spaces for young people to use creative practices and research to assist with life changes and transition. Research in Comparative and International Education, 7, 480-502.

Lally, V., \& Sclater, M. (2013). The Inter-Life project: Researching the potential of art, design and virtual worlds as a vehicle for assisting young people with key life changes and transitions. British Journal of Guidance and Counselling, 41, 318-338.

Laurillard, D. (2002). Rethinking university teaching: A conversational framework for the effective use of learning technologies (2nd ed.). London: Routledge Falmer. doi:10.4324/9780203304846

Leese, M. (2010). Bridging the gap: Supporting student transitions into higher education. Journal of Further and Higher Education. 34, 239251. doi:10.1080/03098771003695494

Lefever, R., \& Currant, B. (2010). How can technology be used to improve the learner experience at points of transition. Electronic paper. Available at:

http://technologyenhancedlearning.net/files/2010/04/ELESIGliteratur ereviewFINAL240210.pdf

Lincoln, Y., \& Guba, E. (1985). Naturalistic inquiry. Beverly Hills, CA: Sage.

Littlejohn, A., Beetham, H., \& McGill, L. (2012). Learning at the digital frontier: A review of digital literacies in theory and practice. Journal of Computer Assisted Learning, 28, 547-556.

doi:10.1111/j.1365-2729.2011.00474.x 
Luckin, R., Clark, W., Graber, R., Logan, K., Mee, A., \& Oliver, M. (2009). Do Web 2.0 tools really open the door to learning? Practices, perceptions and profiles of 11-16-year-old students. Learning, Media and Technology, 34, 87-104. doi:10.1080/17439880902921949

Magill, J., Canavan, B., Devlin, A.M., Trinder, J., Magill, E., \& Pomerantz, M. (2009). A fusion of mobile technology and Second Life ${ }^{\mathrm{TM}}$ in a learning environment to support the transition from school to university. In H. Blackey, A. Jefferies, L. Masterman, \& B. Whalley (Eds). In dreams begins responsibility-choice, evidence and change. ALT/Nuffield Press.

Mayrath, M. C., Traphagan, T., Heikes, E. J., \& Trivedi, A. (2011). Instructional design best practices for Second Life: A case study from a college-level English course. Interactive Learning Environments, 19, 125-142. doi:10.1080/17439880902921949

Merchant, G. (2010). 3D virtual worlds as environments for literacy learning. Educational Research, 52, 135-150. doi:10.1080/00131881.2010.482739.

Miles, M. B., \& Huberman, A. M. (1994). Qualitative data analysis (2nd Edition). Thousand Oaks, CA: Sage.

Minocha, S., \& Roberts, D. (2008). Laying the groundwork for socialisation and knowledge construction within $3 \mathrm{D}$ virtual worlds. ALT-J Research in Learning Technology, 16, 181-196. doi:10.1080/09687760802526699

Minocha, S., Tran, M. Q., \& Reeves, A. J. (2010). Conducting empirical research in virtual worlds: Experiences from two projects in second life. Journal of Virtual Worlds Research, 3, 3-21.

O'Halloran, K. L. (2012). Multi modal analysis and digital technology. In A. Baldrey, \& E. Montagna (Eds.), Interdisciplinary Perspectives on Multimodality: Theory and Practive. Campobasso: Palladino.

Oliver, M. (2013). Learning technology: Theorising the tools we study. British Journal of Educational Technology, 44, 31-43. doi:10.1111/j.1467-8535.2011.01283.x

Parker, J. D. A., Summerfeldt, L. J., Hogan, M.J., \& Majeski, S. A. (2004). Emotional intelligence and academic success. Examining the transition from high school to university. Personality and Individual Differences, 36, 163-172. doi:10.1016/S0191-8869(03)00076-X

Reason, R. D., Terenzini, P. T., \& Domingo, R. J. (2007). Developing social and personal competence in the first year of college. The Review of Higher Education, 30, 271-299. doi:10.1353/rhe.2007.0012

Robertson, S. L. (2005). Re-imagining and re-scritping the future of education: Global knowledge economy discourses and the challenge to education systems. Comparative Education, 31, 151-170. doi: $10.1080 / 03050060500150922$

Savin-Baden, M., Gourlay, L., Tombs, C., Steils, N., Tombs, G., \& Mawer, M. (2010). Situating pedagogies, positions and practices in immersive virtual worlds. Educational Research, 52, 123-133. doi:10.1080/00131881.2010.482732

Schön, D. A. (1983). The reflective practitioner: How professionals think in action. New York: Basic books.

Schön, D. A. (1991). Educating the reflective practitioner towards a new design for teaching and learning in the professions. San Francisco, CA: Jossey-Bass.

Seale, J. K., \& Cann, A. J. (2000). Reflection on-line or off-line: The role of learning technologies in encouraging students to reflect. Computers and Education, 34, 309-320. doi:10.1016/S0360-1315(99)00052-4

Selwyn, N. (2007). The use of computer technology in university teaching and learning: A critical perspective. Journal of Computer Assisted Learning, 23, 83-94. doi:10.1111/j.1365-2729.2006.00204.x

Selwyn, N. (2010). Looking beyond learning: Notes towards the critical study of educational technology. Journal of Computer Assisted Learning, 26, 65-73. doi:10.1111/j.1365-2729.2009.00338.x

Sfard, A., \& Prusak, A. (2005). Telling identities: In search of an analytic tool for investigating learning as a culturally shaped activity. Educational Researcher, 34, 14-22. doi:10.3102/0013189X034004014

Thomas, D., \& Brown, J. S. (2009). Why virtual worlds can matter. International Journal of Learning and Media, 1, 37-49. doi:10.1162/ijlm.2009.0008

Tinto, V. (1975). Dropout from higher education. Review of Educational Research, 45, 89-125. doi:10.3102/00346543045001089

Tinto, V. (1993). Leaving college: Rethinking the causes and cures of student attrition (2nd ed.). Chicago, IL: University of Chicago Press.

Yang, S.-H. (2009). Using blogs to enhance critical reflection and community of practice. Educational Technology and Society, 12, 1121.

Yin, R. K. (2003). Case study research: Design and methods (3rd ed.). London: Sage Publications.

Yorke, M., \& Longden, B. (2008). The first year experience of higher education in the UK: Final Report. York, UK: Higher Education Authority. available at:

http://www.heacademy.ac.uk/assets/York/documents/resources/publi cations/FYEFinalReport.pdf

Warburton, S. (2009). Second Life in higher education: Assessing the potential for and barriers to deploying virtual worlds in learning and teaching. British Journal of Educational Technology, 40, 414-426. doi:10.1111/j.1467-8535.2009.00952.x

Wenger, E. (1998). Communities of practice. Learning, meaning and identity, Cambridge: Cambridge University press.

Wingate, U. (2007). A framework for transition: Supporting "learning to learn" in higher education. Higher Education Quarterly, 61, 391405 . 